\title{
Challenges facing the ministerial formation in Uniting Presbyterian Church in Southern Africa: A critical reflection
}

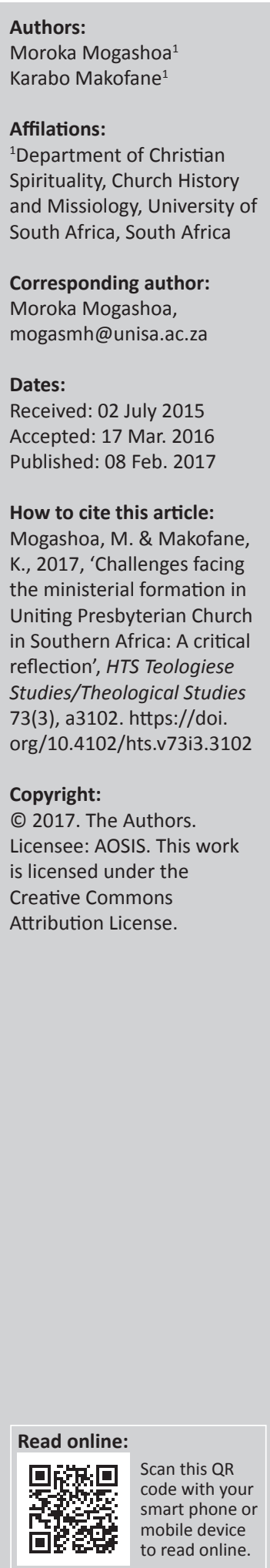

Following the union of the Presbyterian Church of Southern Africa (PCSA) and Reformed Presbyterian Church in Southern Africa (RPCSA) to form the Uniting Presbyterian Church in Southern Africa (UPCSA) in 1999, it was necessary to consolidate theological education of a united church. This was a wise and bold decision by UPCSA, as a first attempt to integrate the training of both black and white students, but more importantly to give institutional expression to the advancement of unity. University of Pretoria (UP) became a major training centre of the UPCSA. Collaboration in ministerial formation between UPCSA and UP, its partner institution, has been plagued by manifold challenges. The challenges which will come under the spotlight are ecumenism, relationship between the university and the UPCSA, curriculum and spirituality.

\section{Introduction}

It is indeed a privilege to contribute a piece in honour of Rev. Professor Graham Duncan. Professor Duncan is a renowned scholar who has a doctorate in both the disciplines of Church History and Missiology and has published extensively in the area of theological education and Presbyterianism theology. He served some theological training institutions such as Federal Theological Seminary of Southern Africa (FEDSEM) as a lecturer and also taught at several institutions of higher education, notably Fort Hare University and University of Pretoria. Through his involvement in theological education he became a mentor to many generations of ministers, academics and theologians of our time. Among them we can single out Profs Maluleke, Vellem, Madise; Drs S. Leleki, M. Raphesu; Revs Z. Makalima, M. Mtyobile, W. Buca, W. Manaka, M. Mohapi, J. Ramantsi, L. Phokontsi and countless others. We saw it befitting to dedicate an article in his honour in one of his research interest areas, namely, ministerial formation in the Uniting Presbyterian Church in Southern Africa (UPCSA) because he has been practically involved in the ministerial formation of the UPCSA.

In this article we use the term ministerial formation because the UPCSA Assembly of 2000 adopted it as the preferred term for the process of preparing members for ministry (UPCSA 2000:271). The other term linked to ministerial formation is theological education which, according to Naidoo (2012:168), is associated with the academic study of theology and personal spiritual growth. We will use both concepts interchangeably.

According to Kritzinger (2010:212) ministerial formation denotes a 'holistic' formation of church members' ministry which should be built on three pillars of intellectual (theological) insight, practical (ministry) skills and personal, spiritual growth. This definition fits well with the ministerial formation vision of the UPCSA Assembly of 2000, which in part reads thus: The Assembly agrees that the aim of ministerial formation should be to integrate the academic, evangelistic, practical and spiritual aspects of training, to take account of the Reformed tradition and to be open to transformation (UPCSA 2000:271).

The UPCSA came into existence on 26 September 1999 in Port Elizabeth, Eastern Cape, through the unification of the Reformed Presbyterian Church in Southern Africa (RPCSA) and Presbyterian Church in Southern Africa (PCSA). The two churches had very different backgrounds, even though they shared the same Scottish heritage (Tucker 2012:1). The PCSA was established among soldiers and settlers, mainly of Scottish origin, who arrived at the Cape in 1820 and became essentially a privileged 'settler' church even though later it extended its mission work among indigenous people. The mission activities of Church of Scotland gave birth to Bantu Presbyterian 
Church in South Africa (later renamed RPCSA in 1923) after it became an autonomous indigenous church.

Ministerial formation (or theological education) was always the pride and cornerstone of both the former PCSA and RPCSA. Therefore, it is not surprising that by the middle decades of the twentieth century the two churches had partnered with the Methodist, Congregational and Anglican churches to form two strong schemes of theological training. In this article we give a brief historical account of theological education in both the former PCSA and RPCSA and proceed to identify some of the challenges ministerial formation is facing since the two churches merged to form a united church, namely the UPCSA, and suggest a constructive proposal for the way forward. The challenges which have been identified in this article are ecumenism, the relationship between church and university, and challenges related to language and spirituality, which will feature under the Africanisation of the curriculum. The list of some of these pressing challenges which have been highlighted in this article is by no means exhaustive of other matters of concern related to ministerial formation in the UPCSA.

\section{Historical outline of Presbyterianism theological education}

According to Denis and Duncan (2011:10) the early history of theological education in the Presbyterian tradition can be traced to the birth of Lovedale Missionary Institution in 1841, established by Scottish missionaries. Even though the theological programme was first introduced by 1870 , already in 1834 missionaries in their assessment of the first 10 years of Lovedale Institution, among other things, cited theological training as a priority. Hence in 1845 the first principal of Lovedale, William Govan, at the meeting of Institutional Board expressed a need to train students for ministry (Denis \& Duncan 2011:11).

Duncan (2012:65) notes that since the inception of Lovedale Missionary Institution openness to ecumenism was one of the hallmarks of Presbyterian theological education in South Africa. As a result of a strong ecumenical commitment when the possibility of ecumenical theological education and ministerial training arose after the Second World War, the Presbyterians joined forces with the Anglicans, Methodists and Congregationalists to form two strong schemes of theological training.

According to Kumalo and Richardson (2010:265) by 1947 the new ecumenical state-funded Faculty of Divinity was established at Rhodes University in Grahamstown, Eastern Cape and the founding denominations were Presbyterian, Methodist, Anglican and Congregationalist. Duncan (2012:65) states that this first scheme was to last until 1999 and was initially only exclusively for white students even though at the tail end of apartheid admission was open to black students. In 1963 the same churches partnered in another ecumenical theological training venture and established FEDSEM at Alice in the Eastern Cape (later relocated to Pietermaritzburg).
Denis and Duncan (2011:2) assert that that majority of students who trained at FEDSEM were mainly but not exclusively black and the staff was racially mixed.

As Kumalo and Richardson (2010:236) rightly point out FEDSEM demonstrated institutional expression to the values of ecumenism and we must add, it became a beacon of hope in a country which was racially polarised and dominated by segregation. Former president of Southern African Council of Churches, Professor Tinyiko Maluleke in Denis and Duncan (2011:2) puts it succinctly: 'the seminary constituted an independent, alternative and counter-hegemonic educational model in a country where black had little access to institutions of higher learning, it was a small island of a multiracial, multi denomination and alternative community in a sea of a larger society where Black was Black and White was White'.

Sadly, owing to inter alia, the winds of change in higher education sector in the early 1990s, these two schemes of theological training suffered a major blow when they ceased operation (FEDSEM in 1993 and Rhodes University's Faculty of Divinity in 1999). This article will not dwell much on the reasons behind the demise of ministerial training schemes at both Rhodes University (Faculty of Divinity) and FEDSEM, only to suffice that one finds it unfortunate especially in the case of FEDSEM that it survived the wrath of apartheid but was unable to survive the post-apartheid era.

As a result of the closure of FEDSEM and the Faculty of Divinity at Rhodes University, both the PCSA and RPCSA had to take interim measures to continue training candidates for ministry. In 1994 all candidates for ministry in the RPCSA were trained at the University of Fort Hare, whereas former PCSA candidates forged links with various theological training institutions for ministerial training of students.

According to Duncan (2012:66), the merger between PCSA and the RPCSA to form UPCSA in 1999 also had serious implications on theological training for a united church. In this regard, the 2001 General Assembly of UPCSA, which met in Johannesburg, endorsed the decision to integrate the training of both the former PCSA and RPCSA. The University of Pretoria (UP) became the theological training of choice for UPCSA in 2002. We will now turn our attention to emerging challenges in ministerial formation in the UPCSA since the decision to partner with UP in 2002.

\section{Emerging challenges to ministerial training and formation in the UPCSA}

What are some of the challenges ministerial training and formation in the UPCSA has faced since opting for UP to become the major church training centre in 2002, in an attempt to integrate the training of black and white ministers? Special attention will be paid to the following challenges: ecumenism, the relationship between church and university, 
and challenges related to language and spirituality, which will feature under the Africanisation of the curriculum.

\section{Ecumenism and ministerial formation in the UPCSA}

Conradie (2013:18-60) lucidly explores 23 different forms of what the term 'ecumenicity' may mean. He contends that given different connotations ascribed to the term 'ecumenical' one should always guard against monolithic definition of this notion. In view of this, we will discuss one of the notions of ecumenicity namely 'ecumenical theological education' which arguably has been the pride and legacy of former PCSA and RPCSA. This point is further confirmed by Duncan (2012:65) when he states that since the existence of Lovedale Missionary Institution in 1870 Presbyterian theological education in South Africa was always driven by spirit of ecumenism. As we have already mentioned this fervour for ecumenical theological education was also demonstrated when the Presbyterians partnered with other ecumenical churches in establishing two exciting new ecumenical training schemes the Rhodes University Faculty of Divinity and FEDSEM. According to Richardson and Leleki (2010:236) these two institutions symbolised spirit of ecumenism in Southern Africa.

However, by the end of the twentieth century, both ministerial training schemes at FEDSEM and Rhodes had collapsed. The closure of the two schemes in the 1990s almost coincided with the dawn of democracy which Kumalo and Richardson (2010:265) describe as a 'tragic irony' for the simple reason that both schemes managed to overcome the tyranny of apartheid yet they succumbed to its demise. Secondly, the closure of these two schemes did more harm to relations among participating churches and to theological education and ministerial training in particular. Richardson (2007:143) claims efforts towards healing and forgiveness among all stakeholders involved in these two theological education ventures, especially in the case of FEDSEM, have proven fruitless.

Sadly, with the closure of the two denominational training schemes in the 1990s the constituent churches fled into their own denominational training schemes and unfortunately no concerted efforts were made to salvage the ecumenical gains from the wreckage (Richardson \& Leleki 2010:237). As a result the training of ministers by the previously participating churches was characterised by unsettled and nomadic experience as they explored possibilities of finding the most viable location in each separate case. According to Richardson (2007:144), in 1994 the Presbyterians returned to their historic roots at Lovedale in the Eastern Cape and for a short stint partnered with the University of Fort Hare. Unfortunately, as Duncan (2012:66) rightly observes, only black students of all Presbyterian denominations were part of this interim arrangement; meanwhile white students of the same church opted for various institutions other than Fort Hare University. It is interesting and ironic that by 1994 as the country was celebrating the demise of apartheid the Presbyterian theological education was still an embodiment of segregation. However, on one hand it should not come as a surprise, as Richardson reminds us, that although theological education schemes of the churches who were affiliated to Rhodes University denounced apartheid, they were ironically enclaves of segregation. Even though by the late 1980s this picture was beginning to change slowly, with a few black students being sent to Rhodes, it is clear the pattern was not easy to dismantle.

The unification of the PCSA and RPCSA in 1999 meant it was necessary to re-align theological education. Duncan (2012:66) asserts that after much investigation and discussion various options were considered as the new ministerial centre of training for the united church. In 2002 it was agreed that UP would become the theological training home of the UPCSA. According to one of the participants, who was part of the UPCSA Assembly of 2001, where this proposal was overwhelmingly approved, this decision was an important milestone, because it meant for the first time UPCSA was one of the major Faculty of Theology partners at UP together with other churches of the reformed family. Furthermore, Duncan (2012:66) notes that the decision was the first attempt geared towards integrating the training of black and white ministers. Unfortunately this vision has not materialised because many white candidates for ministry in the UPCSA prefer to train elsewhere rather than at UP. The continual failure by white candidates of ministry in the UPCSA to train together with their black counterparts is a sign that the integration of training for black and white candidates of ministry in the UPCSA is still a challenge to this day and this can be attributed to separate centres for ministerial formation before the unification which created vested cultural and racial interests that have proven difficult to undo. We therefore concur with De Gruchy (1997, quoted in Richardson 2007:141) that the segregation of theology reflected the reality of segregation in churches. We think it was an excellent move by UPCSA to afford black and white ordinands an opportunity to train together at UP at least for two reasons.

Firstly, the UPCSA students would study together at UP for the sake of fostering and strengthening church unity in a united church. However, as Duncan (2012:66) has indicated previously white candidates of ministry in the UPCSA usually vote with their feet against training at UP. As a result little contact take[s] place between both white and black theological students in the UPCSA at UP and in the process they miss an opportunity to grapple together with the meaning of Scripture or church history for the future of a united church. Secondly, such a move would have gone a long way as stepping stone to transcend the boundaries of race in the ministerial formation of the former PCSA and RPCSA which to a large extent was shaped by century history of estrangement and alienation taken to illogical extremes by apartheid. Owing to this deep-seated estrangement there is a need to cultivate a climate whereby both white and black students in the UPCSA can share stories of anger, fear, pain and hope. As one former UP student attached to the UPCSA 
whom we had the privilege to have a discussion with, rightly pointed out 'the important initial stages of our theological training until completion we literally don't bond with our white counterparts thus doing injustice to the unity of our church'.

Even though Duncan (2012:66) maintains that the decision by UPCSA to partner with UP as a major theological centre signalled a return to an earlier place of Presbyterian theological education, we wonder whether this partnership will continue to be built on the experience of structured unity of the Rhodes and FEDSEM schemes of which UPCSA was a participant. Moreover, the UPCSA has had a long history of theological collaboration with English churches namely, the Anglican, Methodist and Congregational churches, and the two former theological schemes at Rhodes and FEDSEM attest to this. It will be interesting how the UPCSA coexists with the new partner in theological education namely the Dutch Reformed Church, which is a long-standing partner of the Faculty of Theology at UP. Furthermore, will this new partnership venture with UP help UPCSA to produce a new generation of ecumenically oriented, socially aware and critically aware as Denis and Duncan (2011:284) claim was the case with FEDSEM?

Richardson (2007:132) notes that one of the incentives of seminaries operating in partnership with universities is that, staff appointments can be shared between churches and the university. According to one senior source in the UPCSA, closely involved in theological training, that is the case in the agreement UPCSA has with UP (Faculty of Theology). The UPCSA is no stranger to this kind of benefit especially as a church which has a long history of ecumenical theological involvement. For instance, at FEDSEM, the former RPCSA, by sharing human resources with other participating churches in ministerial training alleviated financial burden on salaries of academic and support staff on the part of RPCSA. Gray (1999 quoted in Richardson 2007:132) reminds us that at universities currently around the globe, there is a scramble and jostling for scarce resources and often faculties of humanities and theology are at the receiving end. We argue that the Faculty of Theology at UP, just like at other universities offering theological degrees and subjects elsewhere in the country, is not immune to such onslaughts on humanities, therefore it will be interesting how the UPCSA, as one of the major partners at UP, negotiates such turbulences for the sake of its ministerial training survival. One of the daunting tasks on the side of UPCSA is to ensure that both white and black students train in one institution. As it stands at the moment, it is not healthy for a united church that its black candidates for ministry are training at UP, while their white counterparts train in other institutions, as Duncan (2012:66) has already alluded. Integration of theological education for both prospective white and black ministers would be one way towards advancement of church unity in the UPCSA, but also as an attempt to redress the past history of Presbyterian theological education which was once marked by segregation as Richardson (2007:141) has indicated. Furthermore, if this status quo continues to remain it will have serious cost implications and overstretch the human resources of UPCSA. One source, involved in theological education of the UPCSA, who spoke on condition of anonymity, pointed out that given the limited resources and the vastness of theological training, the UPCSA human resources will be better utilised at one institution (in this case UP) and one can argue that the previous two schemes of theological training at both FEDSEM and Rhodes provided a network of shared resources both human and physical that was rich and varied.

\section{UPCSA and the University as agents of ministerial formation}

According to Duncan (2012:66) the academic component was very central to Presbyterian formation, hence a long history of association with universities such as Rhodes, Fort Hare and recently with UP. However, the academic dimension of ministerial formation is equally important as evangelistic, practical and spiritual aspects of training in the UPCSA (Duncan 2012:66). Klaasen (2012:48) postulates that all four aspects of formation are closely related and of equal value. Who is responsible for ministerial formation in the UPCSA? In the case of the UPCSA the interrelatedness of the church and the partner university is important for holistic ministerial formation (which as we have mentioned above encompasses the academic, evangelistic and spiritual) aspects of formation.

A holistic approach to ministerial formation in the official resolutions (UPCSA 2000:271) cannot be delivered by either university or the church alone. At different stages the different organs of the church (such as, the Ministry Committee of the UPCSA) together with the university share the responsibility for training candidates of ministry. The question is what are the implications of this position? In other words, how does the UPCSA exercise this responsibility and what is the role that a state-funded university play in this formation process?

Even though other organs of the church are responsible for the vocational and personal formation of candidates for ministry, the overall responsibility falls under the institutional oversight of the Ministry Committee of the UPCSA. To this end, the formation of the ministers of the Word becomes the responsibility of the entire church in addition to what they learn at university.

According to Duncan (2012:66) in the UPCSA only ministry students studying at UP are exposed to vocational and pastoral formation before completion of their academic studies. Much of the student formational activities are organised around, the Tiyo Soga Community, whose primary focus is devotional. Duncan (2012:68) notes that much of the life of this community revolves around prayers, weekly communion service and annual valedictory service for departing students. It is interesting to note Presbyterian formation is still continuing with its rich history of residential training which has been inherited from the previous paradigm of theological training. Storey (2004, quoted in 
Richardson 2007:150) argues that the residential training helps to form ministers with integrated intelligence and imagination. Secondly, such training promotes spirit of community. Two former UPCSA students we had the privilege to interact with indicated to us that staying in a student hostel and participating in devotional activities with other ministry students helped to create an environment of comradeship and living together, as a worshipping, learning and caring community. Kritzinger (2010:220) borrowed the African adage 'It takes a village to raise up a child' to illustrate how it has relevance to ministerial formation in Uniting Reformed Church in Southern Africa (URCSA). We maintain that this African proverb is most befitting to ministerial formation in the UPCSA. The ministerial training of UPCSA attempts to live up to this African adage by involving various organs of the church to play active roles in the formation of ministry students; this implies the involvement not only of the wider church, but also local congregations (women's groups, youth groups and so on) of the church.

Because the UPCSA does not subscribe to a mode of formation but varieties of modes of formation, practical ministerial training, currently, is exclusively for ministry students who study at UP. We assume practical orientation for prospective ordination candidates for ministry in the UPCSA who are not enrolled at UP, often takes place at a local institution with attachment to a local church community. In this case spiritual formation takes place in the local church. The challenge with this kind of local training scheme is that minimal exposure to residential training takes place and it becomes extremely difficult to keep good contact and build community among ministry students. Hence, Duncan (2012:68) concludes that ministry students in the UPCSA who do not study at UP are often not well equipped in practical ministerial training. Although one senior source involved in ministerial formation in the UPCSA confirmed to us that the residential training component is factored in these local training schemes. However, like Klaasen (2012:51), we are still convinced the effectiveness of the integration of academic and spiritual formation is minimal.

We think this phenomenon poses a huge challenge to ministerial formation and theological education in the UPCSA. One of the challenges, it seems to us, will be how to keep this phenomenon in creative tension with the residential model of training. Secondly, in a church like UPCSA, where there is a shortage of ministers, and with the escalating high cost at a full-time residential university, it is likely that prospective ordination candidates of ministry in the UPCSA will be attracted to this theological model of training.

It seems to us even though candidates for ministry in the UPCSA studying at UP are expected to do ministerial formation as a requirement, this component of ministry does not enjoy the attention it deserves. Two examples will suffice in this regard. Duncan (2012:68) states that there are no formal assessments of the ministerial formation programme presently in the UPCSA even though evaluation is performed by the Department of Education Innovation at UP and moreover ministerial formation is not part of the formal curriculum.

To meet the vocational aspects of ministerial formation, students are placed at local congregations during term time for practical exposure, however, according to Duncan (2012:68) there is no uniformity regarding expectations of such an exercise and this is left to the discretion of individual ministers. Vocational aspects of ministerial formation require a sensitive mentorship process by well selected and prepared UPCSA ministers. A manual to guide UPCSA ministers in such a mentoring process is an urgent priority, to avoid ministers using their own discretion in carrying such an important task.

Practical ministry experience in the UPCSA should constitute part of the curriculum, we would argue, because the underlying logic of formation for ministry takes place best in the back-and-forth journey between classroom, theology lectures and pastoral encounters as suggested by Kritzinger (2010:223). This kind of an exercise will enable students to encounter challenges and questions in their practical experiences that will have an impact on their theological reading and discussions, and they will begin to see the value of the interplay between theory (what they encounter in lectures or books) and practice. The idea is that students should be active participants in the ongoing life of a UPCSA congregation from week to week during the year.

We think one of the reasons vocational training in the UPCSA is given less attention can be attributed to the theological assumption in the Reformed tradition that formation cannot be formalised and taught. Burger and Nell (2012:18) maintain that even currently there is a certain degree of uneasiness among certain quarters of the Reformed family of churches regarding the word formation. The general assumption is that formation will take place later once students are ordained and in congregations.

Because the UPCSA is advocating for holistic ministerial formation which includes the dimensions of academic insight, evangelistic, practical and spiritual growth, it seems to us that the interrelatedness between the church and the partner university is important. The church has the necessary resources to provide practical training, whereas the university is most appropriate for academic excellence. We concur with Klaasen (2012:59) combining the two institutions can go a long way in contributing towards the most effective ministerial formation. The two institutions should not be viewed as mutually exclusive, but as complementing each other in dispensing the holistic formation the UPCSA is striving for. The litmus test for UPCSA is whether it will have the capacity to sustain and carry the responsibility for holistic ministerial formation in collaboration with its partner university. What can, and should it expect from a faculty of theology at a state-funded university and on one hand maintain its confessional aspirations? 


\section{Africanisation of the curriculum and ministerial formation in the UPCSA}

Theologians in the UPCSA (Duncan 2012:70; Khabela 2000:11; Masango 2000:5f just to mention a few) have issued a clarion call for ministerial formation curriculum in the UPCSA that should bear the African stamp. Such an appeal is necessitated by, among other things, the shift in Christianity's centre of gravity to the south, of which Africa has become one of the centres (Gerloff 2010:315). According to Tshaka (n.d.:1) statistics continue to bear testimony to this reality and therefore the long-loathed idea of bringing the Reformed faith into serious dialogue with Africa and its people is long overdue. However, as Zwana (2007:78) rightly observes, the shift in Christianity's centre of gravity to the south has meant little, because it is not matched by a sustained reconstructive discourse promoting authentic African epistemologies. Thus Dibeela (2014:240) argues that this will require an epistemological shift that dispels a myth that African meaning systems, such as traditions, rituals, songs, dress and sacraments are barbaric and unintelligent. The contempt and disdain towards African thought can be attributed to what Tshaka (n.d.:7) calls superiority of western paradigms in academy which tend to undermine African experiences and stories. Even though Duncan (2012:70) maintains that Presbyterian formation is beginning to take the African approach seriously, we must ask to what extent UPCSA students continue to seriously engage their Africanity in their theological reflections.

Two former UPCSA students we had the privilege to engage with on this important subject, indicated to us that African theology is not taught as one of the mainstream modules at $\mathrm{UP}$, but is rather treated as a subdiscipline in traditional disciplines such as Systematic Theology. They further bemoaned the fact that prescribed books and lectures largely focus on theological ideas and methods generated from Europe and North America. As a result, the faculty does not expose students sufficiently to the realities and theological riches of the African continent. Makofane (2009:42) warns that one of the dangers of treating African theology as an appendix in theological education is that African students are denied opportunity to deal sufficiently with complex African problems and often become estranged from their communities they suppose to labour (Tshaka n.d.:9). Maluleke (1998) gives an example once related by the doyen of African theology, John Mbiti to illustrate this point:

A young African man had just completed his post-graduate studies in theology and there was a big feast to welcome him home. As the ceremony was on, apparently his sister was possessed by the evil spirits. The community asked the young man to intervene in this regard since his sister's problem was a religious one. However the poor young man pulled out some theological books to see whether they will help him to address the illness but to no avail, it only took an ordinary member of the community to shake the sister and she became healed. (p. 124)

This story above demonstrates that at times the university system, which is still steeped in Western concepts and frameworks, is to a great extent responsible for the disjuncture between theology as an academic subject and the African communities our students serve.

Dibeela (2014:241) contends that an epistemological shift would mean among other things a special effort to include the works of African Christian thinkers and writers in theological curricula. In this respect Kritzinger (2010:229) warns us to guard against a myth that if one wishes to be a serious theologian one must read only 'classics' by which is meant European theologians like Karl Barth, Thomas Aquinas and so on. Nel and Makofane (2014:244) assert that there is an extensive body of literature of African classics which Reformed tradition can tap into if it is to make a lasting contribution in the continent or be relevant for local communities within the UPCSA and the broader Reformed community. Dibeela (2014:241) suggests the works of people such as Gabriel Setiloane, Marcus Garvey, John Mbiti, Jesse Mugambi, Musa Dube, James Amanze as some of the standard prescribed works to which universities can expose students. If the classics of African theology do not yet exist, Kritzinger (2010:229) is leaving that daunting task to South African Reformed tradition to start producing them. A further important consideration for this undertaking to be successful is to explore possibilities of a strong intracontinental cooperation of theological schools, seminaries, churches and universities.

This strategy is, of course, not to suggest that the European classics are useless, but to merely point out that their relevance needs to be tested, and serves as a critical reminder that the various African cultures and churches have indeed produced classics in their own right. Neither are we propagating for a crude Afrocentric (vs. Eurocentric transformation) for UPCSA, but ask the question whether the current theological curriculum respects the cultural and theological worlds inhabited by black students equally as those of white students.

\section{Language policy and curriculum}

Another dimension of Africanisation of the curriculum has to do with language policy. Maseko (2015:13) is advocating for bilingualism and multilingualism in development of the curriculum in our schools and universities. Equally Tshaka (n.d.:8) holds a similar view that translating theology into indigenous languages is important. One of the reasons underlying such a proposal is that African Christianity is lived and practised largely in African indigenous languages and more importantly we learn and express ourselves better in our mother tongue. Maseko (2015:13) notes that mother tongue in the context of South Africa refers to inter alia language that is learnt at home, from birth, and it is also a language that through which cognitive abilities are framed and perfected.

According to Kritzinger (2010:225) language policy in ministerial formation, is a hotly contested issue at traditionally Afrikaans universities and schools. At the moment the faculty 
of theology at UP of which UPCSA is a partner offers separate Afrikaans and English classes for the majority of theology modules. As a result the curriculum at UP (Faculty of Theology) does not foster bilingual theological competence (in English and a student's home language). Many black students including UPCSA students at UP's Faculty of Theology are taught through the medium of English. This means the majority of these students are helped to become theologically competent in English but not in their first language or mother tongue. Furthermore, because Afrikaans students enjoy the benefit of being taught in their own language they tend to encounter fewer challenges when it comes to interpreting and understanding the English textbooks prescribed to them and even finding translation equivalents for theological terms, whereas the black students are simply treated as 'English students' by having lectures in English, which to most is a second or even third language. One of the former students indicated to us, that he finds it an irony that he has been taught in English at UP yet his ministry is among black people to whom he is supposed to preach, counsel and pray in one of the African languages. Hence Kritzinger (2010:226) urges us to raise the contextual question regarding the extent to which there is a genuine transfer from the English class learning to the preaching and praying students do afterwards in African languages.

We suggest that the Faculty of Theology at UP, which UPCSA has partnered with, address the issue of language with utmost seriousness. Because the majority of (UPCSA) students studying at the Faculty of Theology at UP speak different African languages, it is important that these languages represented among students be affirmed and fostered as theological languages in their own right. In other words, the Faculty of Theology, of which UPCSA is a partner, should strive to deliver bilingually competent and interculturally sensitive theology graduates. Each student should demonstrate the ability to communicate the acquired theological insights in their mother tongue and in English.

The implication of this proposal is that African languages be accorded the same status as English and Afrikaans as the medium of instruction in teaching theology at UP's Faculty of Theology. This way the two languages will be affirmed alongside with and together with other African languages such as isiZulu, Sesotho and isiXhosa and not against English and Afrikaans but in creative tension with them. We are not propagating that every lecture should be presented in all 11 languages. One set of strategy to achieve this goal is to invite all students for a session in a particular module where the topic is introduced, then divide them into language-based seminar groups, according to each student's choice (based on their mother tongue language of ministry): Afrikaans, Sesotho, isiZulu, and so on, and then conclude this language-based session by giving all students space and time to share their insights among themselves regarding the translation of the English words of the topic into their mother tongue. By moving back and forth students tap into rich cultural resources such as songs, proverbs, stories, rituals and customs which have a bearing on the topic under discussion. Such an approach can nurture a vibrant theological pedagogy and contribute meaningfully to ministerial formation in the UPCSA.

Kritzinger (2012:243) cautions us that such process is fraught with power dynamics owing to the colonial policies that thrived on, among other things, excluding indigenous languages and elevating Dutch and English (and later English and Afrikaans). Enormous resources in the government and private sector were channelled towards projects such as Afrikaans universities, cultural organisations to enable Afrikaans to develop as a respected intellectual and public language. The numerous Afrikaans and Afrikaans-English dictionaries attest to the huge funds and intellectual resources which were invested in such an endeavour. We share the sentiments of Kritzinger (2012:243) that the urgent challenge of our time is to mobilise and unlock resources into research to produce multilingual and intercultural books and dictionaries to stimulate intellectual explorations and experimentation within-and-between cultural-linguistic communities (including churches). Such a venture requires collaboration with colleagues from academic departments, such as African languages or linguistics, who are competent in African languages to assist in drawing up glossaries and translations. Secondly, such intercultural theological resources can be of great value for vernacular theologising in ministerial formation of the UPCSA and UP's Faculty of Theology would have contributed immensely to the church scene and society at large.

\section{Spirituality}

Zwana (2007:74) reminds us that religions (Christianity included) do not operate in a vacuum; a confluence of factors including, social, political and economic dimensions are important determinants in the operation of any religion. The South African society under apartheid was organised along racial lines and in the process the racial divisions became very much a feature of the church. Tshaka (n.d.:2) warns us that even though apartheid is legally abolished through negotiated settlement, it continues in the mindset of both white and black people of South Africa. Owing to the history of deep-seated alienation and estrangement we should not be surprised that the UPCSA is still struggling to rid itself of the racial spectres of the past. Therefore Duncan (2005:206) is correct in suggesting that racism is an inherent spiritual problem rooted in lifes (sic) and experience. In this respect, I propose that in order to overcome the legacy of exclusion and division of the past UPCSA we need to cultivate both antiracist and inclusively African spirituality.

Kritzinger (2010:231) contends that a 'colour blind' approach, which seeks to deny the realities of history, is not helpful. Similarly Tshaka (2010:134) asserts that a historical view approach to issues of racism encourages an apolitical approach which, in turn, breeds indifference to this problem. An antiracist spirituality should acknowledge the shortcomings of our racialised identities in South Africa over the centuries. Secondly, an antiracist spirituality will be 
informed by two strands, that is, (1) a joyful self-acceptance, coupled with an affirmation of all other people as imagebearers of God and (2) a commitment and sacrifice to dismantle all attitudes, habits and structures that reinforce the oppression of people on the basis of racial or ethnic characteristics, or African country of origin, and to defend the weak against the wicked (Kritzinger 2010:232).

The UPCSA has a diverse membership (i.e. , the poor, middle class, old, young, black and white, foreign nationals etc.); as a result constant tensions and frictions often come to the fore as members try to find their identity in a united church. In the search for alternative models of coexistence spirituality of inclusion which is undergirded by the values of ubuntu (humanness or personhood) can go a long way in affirming and reaching to people who are different. Dibeela (2014:231) holds that the concept of ubuntu is the glue that holds life together. It denotes the interconnectedness of all things. We share the source of life that keeps us alive by breathing the same air, sharing the food that nourishes us, walking together and carrying each other's burdens and celebrating and affirming what is good in each other. When looking at $u b u n t u$ as affirming personhood or humanness and respect for all human dignity, we begin to realise the value of embodying a spirituality of inclusion which reaches out to people who are different and the necessity of consciously thinking them into our lives as part of our worldview.

A united and diverse church such as UPCSA cannot afford to underplay spirituality of inclusion in its ministerial formation as a way of building bonds of solidarity among its members and finding a new common language that will unite members to see themselves as part of the collective and becoming aware of their connectedness. For instance, instead of saying, 'Those black poor communities in the UPCSA struggle with Afrophobia' one can rather say 'in some of our communities in the UPCSA We struggle with the hatred of foreign nationals'. This way a new language of collective ownership in the UPCSA is cultivated.

A spirituality of inclusion informed by the values of $u b u n t u$ is a very important resource the UPCSA can use in its ministerial formation and as it seeks to work towards promoting unity among its rank and file. Such an undertaking will require a commitment of all UPCSA members with spiritual courage and bold humility.

\section{Conclusion}

The closure of FEDSEM and the Rhodes University Faculty of Divinity had a devastating effect on ecumenical ministerial training, and the participating churches (UPCSA included) fled into their own denominational training schemes. Theological and ministerial formation of the UPCSA was marked by a period of unsettled and nomadic experience in a quest to find the most viable location and reshaping its theological training. This vacillation and nomadic experience culminated in the UP Faculty of Theology becoming a major training institutional partner of UPCSA in 2002.
The ministerial formation in the UPCSA is facing a number of challenges since joining forces with UP (Faculty of Theology). These challenges were identified as, ecumenism, the relationship between church and university and Africanisation of the curriculum with special focus on language policy and spirituality. This article attempted to look into these challenges in depth and in some cases suggest a way forward that could address some of these challenges.

Chitando (2010:205) notes that it is difficult to be innovative in disciplines, (such as theology,) that take pride in upholding traditions. Calls for creativity and curriculum transformation are often viewed with suspicion and disdain. Churches like UPCSA which pride themselves with upholding Reformed tradition are often guilty of such charges. The failure to liberate Reformed theology leads to coldness and traditionalism that is soul destroying. A reformed tradition which operates in a legalistic framework will rob UPCSA of an opportunity to open up and hear what God is saying to the church today. We think the Faculty of Theology at UP together with its partner churches (that would include UPCSA) are in a better position to experiment or even to come up with creative new theological pedagogies because the university provides a space where principles of institutional autonomy and academic freedom are essential elements of knowledge production.

\section{Acknowledgements Competing interests}

The authors declare that they have no financial or personal relationships which may have inappropriately influenced them in writing this article.

\section{Authors' contributions}

M.M. and K.M. equally contributed to the research and writing of this article.

\section{References}

Burger, C. \& Nell, I., 2012, 'Ministerial formation in the Dutch reformed Churches', in M. Naidoo (ed.), Between the real and the ideal: Ministerial formation in South African Churches, pp. 17-32, Unisa Press, Pretoria.

Chitando, E., 2010, 'Equipped and ready to serve? Transforming theology and religious studies in Africa', Missionalia 38(2), 197-210.

Conradie, E., 2013, 'Notions and forms of ecumenicity: Some South African perspectives', in E. Conradie (ed.), South African perspectives on notions and forms of ecumenicity, pp. 13-75, Sun Press, Stellenbosch.

Denis, P. \& Duncan, G., 2011, The native school that caused all the trouble: A history of the Federal Theological Seminary of Southern Africa, Cluster Publications, Pietermaritzburg.

Dibeela, P., 2014, 'In pursuit of a liberating humanism- reflections in honour of Allan Aubrey Boesak', in P. Dibeela, P. Lenka-Bula \& V. Vellem (eds.), Prophet from the South Essays in honour of Allan Aubrey Boesak, pp. 226-242, Sun Press, Stellenbosch.

Duncan, G., 2005, 'State of the union: The Uniting Presbyterian Church in Southern Africa, 1999-2004', Studia Historiae Ecclesiasticae XXXXI(2), 189-219.

Duncan, G., 2012, 'Ministerial formation in the South African Presbyterian tradition', in M. Naidoo (ed.), Between the real and the ideal: Ministerial formation in South African Churches, pp. 63-72, Unisa Press, Pretoria.

Gerloff, R., 2010, 'The African diaspora and the shaping of Christianity in Africa: Perspectives on religion, migration, identity and collaboration', Missionalia 38(2), 307-320.

Khabela, M.G., 2000, 'Race, ethnicity, ordination and titles', Unpublished paper, Propellor Conference, Johannesburg, 26-29th June.

Klaasen, J., 2012, 'Ministerial formation in the Anglican Church of Southern Africa', in $\mathrm{M}$. Naidoo (ed.), Between the real and the ideal: Ministerial formation in South African Churches, pp. 48-62, Unisa Press, Pretoria. 
Kritzinger, J.N.J., 2010, 'Ministerial formation praxis in the Uniting Reformed Church in Southern Africa: In search of inclusion and authenticity', Missionalia 38(2) in Southern

Kritzinger, J.N.J., 2012, 'Overcoming theological voicelessness in the new millennium', Missionalia 40(3), 233-250.

Kumalo, S. \& Richardson, N., 2010, 'Seth Mokitimi and education for ministry: What's in a name?' Missionalia 38(2), 259-274.

Makofane, K.M., 2009, 'The moratorium debate in Christian mission and the Evangelical Lutheran Church in Southern Africa', MTh thesis, University of South Africa.

Maluleke, T.S., 1998, 'African traditional religions in Christian mission and Christian scholarship: Re-opening a debate that never started', Religion and Theology 5(2), 121-137. http://dx.doi.org/10.1163/157430198X00011

Masango, M.J., 2000, 'Ministry: By whom, for whom, and how?', Unpublished paper, Propeller Conference, Johannesburg, 26-29th June.

Maseko, P., 2015, 'Value of language priceless for nation's growth', Sowetan, 6 March, p. 13.

Naidoo, M., 2012, 'Ministerial formation in South Africa: The way forward', in M Naidoo (ed.), Between the real and the ideal ministerial formation in South African Churches, pp. 157-177, Unisa Press, Pretoria.
Nel, R.W. \& Makofane, K.M., 2014, 'Re-imagining African Reformed Praxis in theological education: A Missiological dialogue with Northern Theological Seminary (NTS)', Studia Historiae Ecclesiasticae XL, 231-248.

Richardson, N., 2007, 'Ministerial training and theological education in the Methodist Church of Southern Africa: The road ahead', Missionalia 35(2), 131-152.

Richardson, N. \& Leleki, S., 2010, 'From ecumenical experiment, to denominational necessity, to holistic vision: The Methodist journey in ministerial training', Missionalia 38(2), 235-247.

Tshaka, R., n.d., 'Academic theology as the yardstick of being reformed in South Africa today: An appreciative critique of Calvin on the occasion of his 500th birthday', Unpublished paper, pp. 1-14.

Tshaka, R.S., 2010, 'Do our theological methodologies help us to deal with situations of violence in Black communities, specifically Afrophobia?' Journal of Theology for Southern Africa 138, 124-135.

Tucker, A.R., 2012, 'Financially resourcing the ministry in the Uniting Presbyterian Church in Southern Africa in the 21st century', Verbum et Ecclesia 33(1), 1-12. http://dx.doi.org/10.4102/ve.v33i1.695

UPCSA, 2000, Proceedings and decisions of general assembly, UPCSA, Johannesburg.

Zwana, S., 2007, 'Church-related universities as a manifestation of new frontiers in mission: The Zimbabwean experience', Missionalia 35(2), 71-88. 